\title{
ABSTRACTS
}

\section{The TRC's Balancing of Law, Religion and Economics in South Africa -A Model for Alternative Dispute Resolution?}

\author{
By Frank Diedrich, Potchefstroom / Rostock
}

The idea to heal (!) a society from gross violations of human rights in the past and to form a newly united society through "story telling" combined with amnesty and compensation was for South Africa a sensible and lucky choice. Already the use of a medical term ("to heal") instead of a judicial, e.g. bringing justice, shows the specific focus of the TRC. The winners of the past-apartheid era could have instead installed Nuremberg-like trials with the full programme of criminal verdicts for a few prominent figures on the basis of so-called "universal human rights".

The common basis found in Christianity throughout the South African society made the work of the TRC easier and, to a great extent, also successful. The setting-up of a TRC with the competence of granting amnesty was for the Republic of South Africa the most reasonable choice in contrast to individual court trials or "show-trials".

The economic side of the TRC concerned reparations paid to the victims of apartheid violence and businesses favoured by the apartheid regime. The TRC only managed to address the first issue in concrete terms by recommending precise numbers for reparation per victim but mostly just the urgent interim reparations from the President's Fund were actually paid out. The business community was addressed during the institutional hearings where the TRC was careful enough to demand neither any precise amount to be paid to suppressed businesses nor to advocate any detailed plan to re-distribute any wealth accumulated by certain businesses because of apartheid laws. Thus the TRC avoided an open conflict with the industry and businesses.

Due to the TRC's unique historical, religious and political background, the spontaneous rule-making and its "liturgy" resulting from a deeply rooted religiousness in South Africa makes it almost impossible to transfer its methods to the world of ADR. However, the idea of reconciling hostile parties by having also a look into their individual cultural, political and religious background might be an idea worthwhile considering in the otherwise economically centered ADR in national and international commercial disputes. 


\title{
Theory and Reality of the Iranian Constitution
}

\author{
By Parinas Parhisi, Frankfurt/Main
}

The article intends to provide an overview on characteristic elements of the Iranian constitution with special consideration of both the constitutional principles and the government system, including their intrinsic antinomies and contradictory factors.

The non-admission of women and minorities to top positions in government is described as substantial deficit which does persist. The precise the position of women under constitutional law is highlighted. Finally the intra-iranian discourse concerning the compatibility of Islam and human rights is addressed.

For Iran or any other comparable nation, it is of utmost importance that a stable democratic system can only develop if it is compatible with religion and culture.

An evaluation of the constitution requires a constructive debate on the various historic eras Iran experienced (Iranian, Islamic, European) to elaborate an adequate solution regarding the roles of women and men.

\section{Democratic Republic of Congo - the Constitution of 2005 (II)}

By Dietrich Nelle, Brüssel

The Democratic Republic of Congo, the sleeping giant of Sub-Saharian Africa, has acquired from the very start of its independence a firmly rooted reputation as a country of civil war, ethnic strife, autocratic leadership, impunity of crime, systematic mismanagement at all levels and large-scale pilling of natural resources. At the same time, taking into account its natural wealth, it is one of the richest countries of the world. The new Constitution endorsed by a clear majority earlier this year could prove to become a turning point in the country's history. In legal terms it marks the end of the transition period created by the peace-process five years earlier and the starting point of the so-called 3rd Republic. Many attach great hopes to these developments although a long way still needs to be gone in order to turn the immense wealth of the country into prosperity for its own inhabitants. The present paper traces the major lines of debate in the process of elaboration of the new Constitution, analyses the major orientations of the reforms adopted and links them to the backdrop of the current state of developments in the relevant fields of Congolese reality. The first part covered the history of congolese constitutions as well as the new governance model. This second part covers the institutions under the new Constitution. 